\title{
THE EFFECTIVENESS OF LUNG TUBERCULOSIS EDUCATIONAL VIDEO TO INCREASE KNOWLEDGE AND ATTITUDES OF MASKS USE IN FAMILIES LIVING WITH TUBERCULOSIS PATIENTS
}

Yati Sri Hayati ${ }^{1 *}$, Venty Aprilia Putri ${ }^{1}$, Mifetika Lukitasari ${ }^{1}$

Afiliasi

Dikirim 4 September 2020

Direvisi 9 November 2020

Diterima 9 November 2020

Dipublikasikan 30 November 2020

*Corresponding author

Email :

yshayati.fk@ub.ac.id

\begin{abstract}
ABSTRAK
Penyakit Tuberkulosis paru masih menjadi perhatian pemerintah sebagai salah satu penyakit menular yang menyebabkan kematian. Prevalensi tuberkulosis paru hingga saat ini masih terus meningkat, salah satu penyebabnya adalah tingginya angka penularan. Keluarga yang merawat pasien tuberkulosis paru mempunyai risiko lebih tinggi untuk tertular karena tingginya intensitas interaksi yang dilakukan. Untuk itu keluarga harus memahami dan menyadari bagaimana penularan tuberkulosis paru dan pencegahannya. Tujuan penelitian adalah untuk mengetahui efektivitas edukasi melalui media video mengenai penularan tuberkulosis paru terhadap peningkatan pengetahuan dan sikap dalam penggunaan masker pada keluarga dengan pasien tuberkulosis paru. Desain penelitian adalah pre-experimental dengan pendekatan one group pre-post test design. Instrumen yang digunakan berupa kuesioner untuk mengukur pengetahuan dan sikap, serta video edukasi dengan durasi 15 menit. Responden pada penelitian ini adalah salah satu anggota keluarga yang menjadi penanggungjawab utama pasien tuberkulosis paru, berjumlah 23 orang. Hasil penelitian diperoleh bahwa nilai mean pre test untuk pengetahuan adalah $71.00 \pm 8.954$ dan sikap adalah 21.65 \pm 4.074 . Sementara hasil post test diperoleh nilai mean pengetahuan adalah $94.70 \pm 6.931$ dan sikap adalah $25.96 \pm 3140$. Terdapat pengaruh yang signifikan pemberian video edukasi penularan tuberkulosis paru terhadap peningkatan pengetahuan dan sikap dalam penggunaan masker pada keluarga dengan pasien tuberkulosis paru. Untuk itu, penggunaan media video edukasi dapat dikembangkan lebih baik lagi sebagai alternatif strategi dalam upaya pencegahan penularan tuberkulosis paru, baik di rumah sakit ataupun di masyarakat.
\end{abstract}

Kata Kunci: pengetahuan, sikap, tuberculosis, video edukasi.$$
\text { ABSTRACT }
$$

Lung tuberculosis is still a government concern as an infectious disease that causes death. The prevalence of lung tuberculosis is still increasing, one of the causes is the high rate of transmission. Families caring for lung tuberculosis patients have a higher risk of transmitted because of the high intensity of interactions. Families must understand and be aware of how lung tuberculosis is transmitted and how to prevents it. The research objective was to determine the effectiveness of education through video regarding lung tuberculosis transmission towards increasing knowledge and attitudes in using masks in families with lung tuberculosis patients. The research design was pre-experimental with one group pre-post test design. The instrument used was a questionnaire to measure knowledge and attitudes, and an educational video with a duration of 15 minutes. Respondents in this study are one of the family members who are the main responsible for tuberculosis patients, totaling 23 people. The results showed the mean pre-test for knowledge was $71.00 \pm 8,954$ and attitudes were $21.65 \pm 4.074$. Meanwhile, after providing education, the results showed the mean of knowledge is $94.70 \pm 6.931$ and the attitude is $25.96 \pm 3140$. There was a significant effect of providing lung tuberculosis transmission educational videos on increasing knowledge and attitudes in using masks in families with lung tuberculosis patients. The use of educational video media can be better developed as an alternative strategy in efforts to prevent lung tuberculosis transmission, both in hospitals and in the community.
\end{abstract}

Keywords: attitude, educational video, knowledge, tuberculosis.

Sitasi jurnal :

Hayati YS, Putri VA, Lukitasari M. 2020. The Effectiveness Of Lung Tuberculosis Educational Video To Increase Knowledge And Attitudes Of Masks Use In Families Living With Tuberculosis Patients. Jurnal Ilmu Keperawatan 8(2): 128-134. Doi: 10.21776/ub.jik.2020.008.02.10 


\section{PENDAHULUAN}

Tuberkulosis paru merupakan salah satu dari 10 penyakit utama di dunia yang menyebabkan kematian. Kejadian Tuberkulosis paru banyak terjadi terutama di negara berkembang, termasuk Indonesia (WHO, 2018). Insiden tuberkulosis paru terus meningkat dan menjadi penyakit re-emergencing sehingga pada tahun 1995 WHO mendeklarasikan tuberkulosis paru sebagai suatu global health emergency (Kemenkes, 2012).

Prevalensi tuberkulosis paru di Indonesia per 17 Mei 2018 sebanyak 420.994 kasus, dan di Jawa Timur dilaporkan kenaikan kasus tuberkulosis, dimana pada tahun 2013 terdapat $0,1 / 100.000$ penduduk menjadi 0,4/100.000 penduduk pada tahun 2018 (Infodatin, 2018). Sementara itu, Kabupaten Ponorogo sebagai salah satu wilayah di Jawa Timur pun melaporkan adanya peningkatan kejadian tuberkulosis paru, dimana pada tahun 2015 sebanyak 70,67/100.000 penduduk dan tahun 2016 meningkat menjadi 93/100.000 penduduk (Dinkes Kab. Ponorogo, 2016).

Peningkatan angka kejadian tuberkulosis paru ini salah satunya disebabkan penularannya yang sangat mudah, yaitu transmisi melalui droplet nuclei yang berada di udara dan mengandung mycobacterium tuberkulosis. Selain itu, transmisi nosokomial merupakan salah satu pendorong utama wabah tuberkulosis paru terutama pada tuberkulosis Multi Drug Resistant (MDR). Penyebaran mycobacterium tuberkulosis terutama terjadi di area indoor atau area yang memiliki pertukaran udara terbatas dan tempat yang ramai dimana banyak orang melakukan aktivitas bersama, seperti rumah sakit (Mathema et al., 2017).

Penyebaran infeksi juga disebab alat pelindung diri yang tidak lengkap. Terdapat 3 level pencegahan penyebaran tuberkulosis paru, yaitu kontrol secara administrasi, kontrol secara lingkungan, dan menggunakan pelindung jalan nafas (Departemen of Health \& Human Service USA, 2010). Pelindung jalan nafas atau masker dapat menurunkan penularan sebanyak 10\% (Migliori et al., 2018) dan mengurangi 50\% risiko penularan (American Thoracic Society, 2011).

National Institute for Occupational Safety and Health (NIOSH) mengemukakan bahwa masker yang dapat digunakan untuk melindungi diri dari penularan tuberkulosis adalah $\mathrm{N}(95,99,100), \mathrm{R}(95,99,100)$, dan $\mathrm{P}(95,99)$. Selain masker tersebut terdapat masker yang biasa digunakan di Indonesia, yaitu N-95 dan masker bedah (Departement Of Health \& Human Service, 2010). Smith et al. (2016) menjelaskan bahwa berdasarkan hasil konfirmasi dengan petugas yang menggunakan masker bedah ataupun masker N-95 tidak terdapat kesenjangan yang tinggi, walaupun dalam hasil penelitian menyatakan bahwa masker N-95 memiliki banyak kelebihan dibandingan dengan masker bedah biasa.

Penggunaan masker yang benar sangat dianjurkan sebagai salah satu cara pencegahan penularan tuberkulosis paru pada keluarga dengan pasien tuberkulosis di rumah sakit (Migliori et al., 2018). Intensitas interaksi dengan pasien tuberkulosis paru yang cukup tinggi serta paparan potensi infeksi lainnya di rumah sakit menjadikan keluarga pasien memiliki risiko penularan yang lebih tinggi (Islam et al., 2015). Namun, fenomena yang ada menunjukkan bahwa masih kurangnya kesadaran keluarga dengan pasien tuberkulosis untuk menggunakan masker selama menjaga pasien di rumah sakit.

Berdasarkan hasil studi pendahuluan, diperoleh bahwa selain masih kurangnya kesadaran keluarga menggunakan masker, juga diperoleh bahwa pengetahuan keluarga tentang penularan penyakit tuberkulosis paru belum memadai. Mayoritas keluarga menyatakan telah mendengar beberapa hal tentang penyakit menular dan mampu menyebutkan beberapa penyakit menular tetapi belum mengetahui secara keseluruhan tentang penularan penyakit serta pencegahannya. Padahal pengetahuan sangat penting dalam kehidupan manusia dan merupakan faktor yang mendasari seseorang untuk bersikap dan berperilaku.

Glanz, Barbara, \& Rimer (2008) menyatakan bahwa pengetahuan dan sikap tentang pencegahan penularan tuberkulosis dipercaya dapat mengubah pola pikir seseorang, dimana cara untuk meningkatkan pengetahuan secara cepat melalui pendidikan kesehatan atau kampanye menggunakan media massa, (Faris, Germossa, \& Beyene, 2018). Pendidikan kesehatan yang umum dilakukan adalah penyuluhan (Friedman, Bowden, \& Jones, 2010). Pendidikan kesehatan juga berkontribusi pada pengetahuan dan perilaku siswa terhadap penyakit menular (Wang, 2018). Media sebagai penyalur pesan dari pendidikan 
kesehatan dan juga mewakili pendidik untuk menyajikan informasi belajar kepada peserta didik.

Pendidikan kesehatan dapat disampaikan melalui berbagai macam media, salah satunya video. Media video merupakan salah satu media yang menggunakan banyak indera tubuh, seperti indera penglihatan dan pendengaran sehingga dalam pembelajaran lebih efektif dan efisien untuk menerima informasi (Dena, 2015). Semakin kompleks indera yang berkontribusi dalam penerimaan pesan dalam pendidikan kesehatan maka semakin banyak pula pesan yang akan terserap oleh peserta didik sehingga mudah dipahami (Suparman, 2012). Media video juga mudah untuk digunakan oleh siapapun dan tidak terbatas oleh waktu. Berdasarkan hal tersebut, maka penelitian ini bertujuan mengetahui efektifitas video edukasi tentang pencegahan penularan tuberkulosis paru terhadap peningkatan pengetahuan dan sikap penggunaan masker pada keluarga dengan pasien tuberkulosis paru.

\section{METODE}

Penelitian ini merupakan penelitian kuantitatif, menggunakan metode pre-experimental dengan pendekatan one group pretest-postest design. Populasi penelitian seluruh keluarga dengan pasien tuberkulosis paru yang dirawat di ruang Asoka RSUD dr. Harjono S Ponorogo. Jumlah responden 23 orang, diperoleh dengan menggunakan teknik concecutive sampling. Responden merupakan anggota keluarga dewasa yang membantu merawat pasien tuberkulosis paru selama di rumah sakit, mampu membaca dan menulis, serta bersedia mengikuti kegiatan penelitian. Pengumpulan data dilakukan pada tanggal 27 September 2019 sampai dengan 31 Oktober 2019. Instrumen penelitian berupa kuesioner untuk menilai pengetahuan dan sikap responden yang telah diuji validitas dan reliabilitasnya serta video edukasi. Kuesioner dan video edukasi yang diberikan mencakup materi tentang pencegahan penularan tuberkulosis paru, yaitu definisi penyakit, cara penularan, alat pelindung diri, serta penggunaan masker. Pengisian kuesioner secara keseluruhan membutuhkan waktu sekitar 30 menit. Prosedur pengumpulan data diawali dengan memberikan kuesioner pre edukasi kepada responden, kemudian dilanjutkan dengan pemberian edukasi melalui media video kepada responden. Setelah itu responden mengisi kembali kuesioner yang sama untuk post edukasi. Video edukasi diberikan 1 kali, dengan durasi 15 menit. Hasil penilaian dari kuesioner pengetahuan dan sikap responden berupa skor yang selanjutnya dianalisis menggunakan uji paired sample t-test untuk variabel pengetahuan dan uji Wilcoxon untuk variabel sikap. Izin etik diperoleh dari Komite Etik Penelitian Kesehatan RSUD dr. Harjono S. Ponorogo dengan Nomor 200/ KEPK/V/2019 pada tanggal 4 September 2019.

\section{HASIL}

\section{Gambaran Karakteristik Responden}

Gambaran karakteristik responden dijelaskan berdasarkan usia, jenis kelamin, pendidian, dan pekerjaan. Responden pada penelitian ini lebih dari setengahnya berjenis kelamin laki-laki 56.5\%, usia responden mayoritas berada di kelompok 30-39 tahun $(30,4 \%)$ dan $40-49$ tahun $(30,4 \%)$, tingkat pendidikan responden paling banyak adalah SMP (39.1\%), serta pekerjaan responden mayoritas adalah swasta (34.8\%) (Tabel 1).

Tabel 1: Gambaran Karakteristik Responden $(n=23)$

\begin{tabular}{lcc}
\hline Karakteristik & $\begin{array}{c}\text { Frekuensi } \\
\text { (n) }\end{array}$ & $\begin{array}{c}\text { Persentase } \\
\text { (\%) }\end{array}$ \\
\hline Jenis Kelamin & & \\
Laki-laki & 13 & $56.5 \%$ \\
Perempuan & 10 & $43.5 \%$ \\
\hline Pendidikan & & \\
SD & 6 & $26.1 \%$ \\
SMP & 9 & $39.1 \%$ \\
SMA/SMK & 2 & $26.1 \%$ \\
S1 & 2 & $34.8 \%$ \\
\hline Pekeriaan & & \\
Swasta & 8 & $34.8 \%$ \\
Tani & 5 & $21.7 \%$ \\
Wiraswasta & 4 & $18.4 \%$ \\
IRT & 6 & $26.1 \%$ \\
\hline Usia & & \\
20-29 tahun & 4 & $17.4 \%$ \\
30-39 tahun & 7 & $30.4 \%$ \\
40-49 tahun & 7 & $30.4 \%$ \\
>50 tahun & 5 & $21.7 \%$ \\
\hline
\end{tabular}

Sumber : data primer yang diolah 


\section{Pengetahuan dan Sikap Responden}

Hasil penelitian menunjukkan bahwa setelah dilakukan intervensi terdapat peningkatan skor minimal variabel pengetahuan sebanyak 28 poin, dan variabel sikap sebanyak 8 poin (Tabel: 2 ).

Tabel 2: Gambaran Pengetahuan Dan Sikap Responden Sebelum dan Setelah Diberikan Intervensi $(\mathbf{n}=\mathbf{2 3})$

\begin{tabular}{lcc}
\hline & Pengetahuan & Sikap \\
\hline Pre-test & & \\
Min & 50 & 11 \\
Max & 92 & 30 \\
Median & 71.00 & 22.00 \\
\hline Post-test & & \\
Min & 78 & 19 \\
Max & 100 & 32 \\
Median & 100.00 & 27.00 \\
\hline
\end{tabular}

Peningkatan pengetahuan responden yang signifikan juga dapat dilihat dari nilai rata-rata sebelum intervensi $71.00 \pm 8.954$ dan setelah intervensi $94.70 \pm 6.931$, nilai negative ranks sebanyak 0 responden dan positive ranks sebanyak 23 responden, serta $p$-value $=0,000$ (Tabel 3).

Tabel 3: Perbedaan Rata-rata Pengetahuan Responden Sebelum dan Setelah Intervensi $(n=23)$

\begin{tabular}{lll}
\hline & Pre-test & Post-test \\
\hline N & 23 & 23 \\
Mean & $71.00 \pm 8.954$ & $94.70 \pm 6.931$ \\
Negative Ranks & & $0^{\mathrm{a}}$ \\
Positive Ranks & & $23^{\mathrm{a}}$ \\
p-value & .000 \\
\hline
\end{tabular}

Sementara peningkatan sikap responden yang signifikan dapat dilihat dari nilai rata-rata sebelum intervensi $21.65 \pm 4.074$ dan setelah intervensi $25.96 \pm 3140$, dan $p$-value $=0,000$ (Tabel 4).

Tabel 4: Perbedaan Rata-rata Sikap Responden Sebelum dan Setelah Intervensi $(n=23)$

\begin{tabular}{lll}
\hline & Pre-test & Post-test \\
\hline $\mathbf{n}$ & 23 & 23 \\
Mean & $21.65 \pm 4.074$ & $25.96 \pm 3140$ \\
p-value & & .000 \\
\hline
\end{tabular}

\section{PEMBAHASAN}

\section{Pengetahuan Responden}

Hasil penelitian menunjukkan bahwa video edukasi pencegahan penularan tuberkulosis paru secara signifikan dapat meningkatkan pengetahuan dan sikap penggunaan masker pada keluarga dengan pasien tuberkulosis paru. Hal ini dibuktikan dengan hasil uji yang menyatakan adanya perbedaan sebelum dan setelah dilakukan intervensi. Peningkatan skor pengetahuan sangat signifikan terutama pada item tentang salah satu manfaat masker ("masker mencegah dari terkena cairan tubuh: keringat, $\mathrm{BAB}$, dan BAK"), dimana sebelum intervensi hanya terdapat 3 responden yang menjawab benar dan setelah dilakukan intervensi terdapat 20 responden yang menjawab benar.

Hasil penelitian ini sejalan dengan penelitian Ummami (2016) yang menyatakan bahwa terdapat pengaruh pendidikan kesehatan tentang tuberkulosis terhadap peningkatan pengetahuan dan sikap penderita dalam pencegahan penularan tuberkulosis di Puskesmas Simo. Selain itu, Mulyadi, Warjiman, \& Chrisnawati (2018) dalam penelitiannya juga menyatakan bahwa pendidikan kesehatan dapat mengubah pengetahuan responden dari kategori kurang baik menjadi baik.

Pendidikan kesehatan dapat diberikan dengan metode dan media yang bervariasi. Penggunaan alat bantu media dalam memberikan pendidikan kesehatan atau edukasi merupakan salah satu komponen yang penting diperhatikan agar informasi yang disampaikan lebih menarik dan mudah dipahami oleh sasaran. Video merupakan salah satu media edukasi yang sesuai dengan perkembangan saat ini dimana teknologi informasi semakin canggih. Kelebihan video lainnya sesuai dengan Mulyadi, Warjiman, \& Chrisnawati (2018) bahwa pesan yang disampaikan melalui gambar dan suara menjadi lebih ringkas, sehingga mudah untuk dipahami.

Selain itu, Baitipur \& Widraswara (2018) mengungkapkan bahwa fasilitas berupa alat peraga (media) berfungsi untuk membantu dan memperagakan sesuatu dalam proses pendidikan kesehatan. Media ini digunakan berdasarkan prinsip bahwa pengetahuan yang ada pada setiap manusia itu 
diterima dan ditangkap melalui panca indera. Semakin banyak indera yang digunakan semakin banyak dan semakin jelas pula pengetahuan yang diperoleh. Sehingga pemilihan media yang tepat mampu mentransfer informasi pendidikan kesehatan dengan lebih mudah. Baitipur \& Widraswara (20180 juga menambahkan bahwa media video akan membuat responden aktif dalam kegiatan pendidikan kesehatan karena responden dapat mengamati pesan yang tertuang dalam video tersebut.

Perubahan pengetahuan akan terjadi pada sasaran jika edukasi kesehatan yang diberikan didukung oleh materi dan media pendidikan yang disampaikan secara menarik. Salah satu media edukasi yang menarikadalah melalui video karena dalam video terdapat gambar bergerak dan suara sehingga mempermudah sasaran untuk memahami informasi yang disampaikan. Media video dinilai lebih menarik bagi seseorang sehingga

\section{KESIMPULAN}

Terdapat peningkatan pengetahuan dan sikapyang signifikan tentang penggunaan masker pada keluarga dengan pasien tuberkulosis paru setelah memperoleh intervensi video edukasi pencegahan penularan

\section{DAFTAR PUSTAKA}

American Thoracic Society, A. (2011). Simple Face Masks Could Significantly Prevent Spread of TB to Non Infected Patients. Infection Control Today, 1-2. Retrieved from http://www. infectioncontroltoday.com/news/2011/05/ simple-face-masks-could-significantly-preventspread-of-tb-to-non-infected-patients.aspx

Azwar, S. (2011). Sikap Manusia: Teori dan Pengukurannya. Yogyakarta: Pustaka Pelajar.

Baitipur, L. N., \& Widraswara, R. (2018). Pendidikan Kesehatan Melalui Video Untuk Meningkatkan Pengetahuan dan Praktik PSN DBD. Journal of Health Education, 3(2), 57-60. https://doi.org/ 10.1080/10556699.1994.10603001

Budiman, A. R. (2013). Kapita Selekta Kuesioner (I). Jakarta: Salemba Medika.

Dena, S. (2015). Pengaruh Media Leaflet dan Media Video Terhadap Pengetahuan dan Sikap MAhasiswa Dalam Upaya Deteksi Dini Kanker ketercapaian tujuan pendidikan kesehatan akan lebih optimal (J, H., Oktavidiati \& Astuti, 2019).

Penelitian ini juga menunjukkan bahwa pemberian media video memberikan dampak pada peningkatan sikap tentang penggunaan masker pada keluarga dengan pasien tuberkulosis paru. Hasil ini sesuai dengan Azwar (2011) bahwa faktor yang mempengaruhi sikap seseorang adalah pengalaman pribadi, pengaruh orang lain, kebudayaan, media massa, dan faktor emosional. Pendapatlain menyatakan bahwa seseorang dalam bersikap dipengaruhi oleh beberapa faktor, diantaranya yaitu kepribadian, intelejensi, dan minat (Budiman, 2013). Pengalaman responden mengikuti pendidikan kesehatan melalui video edukasi memberikan tambahan informasi atau pengetahuan bagi responden dan menjadi dasar untuk menentukan sikap.

tuberkulosis paru. Edukasi kesehatan melalui video sebaiknya semakin banyak dikembangkan sebagai salah satu media promosi kesehatan di masyarakat yang efektif.

Payudara di Akademi Keperawatan Pemerintah Kabupaten Tapanuki Utara. Tapanuki Utara: Akper Pemkab Tapanuki Utara.

Departement Of Health \& Human Service USA. (2010). Respiratory Protection in Health-Care Settings. CDC: TB Elimination, (April), 1-2.

Dinkes Ponorogo. (2016). Kabupaten Ponorogo Tahun 2014.

Faris, A. M., Germossa, G. N., \& Beyene, D. T. (2018). Knowledge, Attitude And Practice On Prevention And Control of Tuberculosis Among Bilida Kebele Residents, Mana Woreda, Jimma Zone, Oromia Region, South West Ethiopia. Health Science Journal, 12(5), 10-13. https://doi. org/10.21767/1791-809X.1000589

Friedman, M. M., Bowden, V. R., \& Jones, E. G. (2010). Buku Ajar Keperawatan Keluarga: Riset, Teori \& Praktik. Jakarta: EGC.

INFODATIN. (2018). Tuberkulosis. InfoDATIN, 1-6. https://doi.org/2442-7659 
Islam, M. S., Luby, S. P., Sultana, R., Ali, N., Zaman, R. U., Uddin, M., ... Branch, D. D. (2015). Family caregivers in public tertiary care hospitals in Bangladesh : Risk and opportunities for infection control. Am J Infect Control., 42(3), 305-310. https://doi.org/10.1016/j.ajic.2013.09.012. Family

J, H., Oktavidiati, E., \& Astuti, D. (2019). Pengaruh Pendidikan Kesehatan Media Video dan Poster terhadap Pengetahuan dan Sikap Anak dalam Pencegahan Penyakit Diare. Jurnal Kesmas Asclepius, 1(July). https://doi.org/10.31539/ jka.v1i1.747

Glanz, K., Rimer, B.K., \& Viswanath, K. (2008). Health Behavior and Health Education: Theory, Research, and Practice. 4 Edtion. San Francisco: John Wiley \& Sons, Inc.

Kementerian Kesehatan Republik Indonesia. (2016). Peraturan menteri kesehatan republik indonesia nomor 67 tahun 2016 tentang penanggulangan tuberkulosis.
Mathema, B., Andrews, J. R., Cohen, T., Borgdorff, M. W., Behr, M., Glynn, J. R., Wood, R. (2017). Drivers of Tuberculosis Transmission. Journal of Infectious Diseases, 216(January), S644-S653. https:// doi.org/10.1093/infdis/jix354

Migliori, G. B., Ambrosio, L. D., Centis, R., Boom, M. Van Den, Ehsani, S., \& Dara, M. (2018). Guiding Principles to Reduce Tuberculosis Transmission in the WHO European Region. WHO, 1-51.

Mulyadi, M. I., Warjiman, \& Chrisnawati. (2018). Efektivitas Pendidikan Kesehatan Dengan Media Video Terhadap Tingkat Pengetahuan Perilaku Hidup Bersih Dan Sehat, 001.

Kemenkes RI. (2012). Pendoman Pencegahan dan Pengendalian Infeksi Tuberkulosis Di Fasilitas Pelayanan Kesehatan,

Smith, J. D., Macdougall, C. C., Johnstone, J., Copes, R. A., Schwartz, B., \& Garber, G. E. (2016). Effectiveness of N95 respirators versus surgical masks in protecting health care 